\title{
Analisis Pengaruh Faktor Internal dan Faktor Ekternal terhadap Kinerja Reksa Dana Syariah Saham
}

\section{The analysist of internal and external factor influences on Islamic equity funds performance}

\section{Fathimah Awliyaul Alim}

Program Studi Keuangan Syariah, Politeknik Negeri Bandung

Email: fathimahawliya@gmail.com

\section{Muhamad Umar Mai}

Jurusan Akuntansi, Politeknik Negeri Bandung

Email: umar.mai@polban.ac.id

\section{Setiawan}

Jurusan Akuntansi, Politeknik Negeri Bandung

Email: setiawan@polban.ac.id

\begin{abstract}
This research aims to find out what things can affect the performance of I slamic equity funds. Four independent variables were taken based on research released and classified as internal factors (Stock Selection, Mutual Fund Age) and external factors Jakarta Islamic Index and Inflation Rate) to initiate the relationships in the performace of sharia equity funds as the dependen variables. The performance of Islamic equity funds use the Sharpe method and calculated for 36 months from January 2017 to December 2019. Research data taken from secondary data published by Bareksa, Jakarta Islamic Index and Bank. Indonesia. Research method uses quantitative-descriptive in path analysis model. The result shows that Stock Selection, Mutual Fund Age, and Jakarta Islamic Index significantly influence the performace of sharia equity funds. Meanwhile the Inflation Rate doesn't significantly influence the performace of sharia equity funds.
\end{abstract}

Keywords: sharia mutual fund performance, stock selection, mutual fund age, Jakarta I slamic Index, inflation rate, sharpe method.

\section{Pendahuluan}

Banyak orang melakukan investasi terkait dengan tuntutan akan kebutuhan dana dimasa yang akan datang. Seiring berkembangnya zaman, berinvestasi seperti investasi berbentuk efek dipasar modal juga dapatmenjadi satu pilihan bagi masyarakat selain berbentuk investasi tanah, kendaraan, atau lainnya.

Saham dan obligasi dikenal sebagai instrument yang paling sering digunakan dalam transaksi pasar modal, terutama bagi kalangan yang telah terbiasa melakukan investasi di pasar modal. Namun tentu saja pasar modal bukan hanya diciptakan untuk kalangan tertentu, melainkan juga untuk masyarakat keseluruhan. Dengan semakin banyaknya pihak yang terlibat, tentu akan berdampak pada berkembangnya pasar modal di Indonesia dan meningkatnya minat dan literasi masyarakat terkait investasi di pasar modal. 
Bagi kalangan yang telah terbiasa berinvestasi di pasar modal, saham dan obligasi tentu menjadi pilihan yang tepat untuk menanamkan modal. Namun bagi para pemula atau masyarakat awam yang belum mengenal pasar modal secara umum, belum atau bahkan tidak memiliki nominal investasi yang besar dan ketidaktahuan akan tata cara pengelolaan portofolio efek, menanamkan modal langsung pada saham dan obligasi dirasa kurang tepat. Maka dari itu, hadirlah reksadana sebagai salah satu instrument berbentuk portofolio efek yang cocok bagi para pemula karena memiliki nominal investasi yang relatif kecil dengan disertai adanya bantuan dari manajer investasi atau fund manager sebagai pengelola reksadana pemodal supaya mampu dikelola secara produktif.

Berdasarkan Undang-Undang No. 8 Tahun 1995, pasal 1 ayat 27 tentang Pasar Modal, "Reksadana adalah wadah yang dipergunakan untuk menghimpun dana dari masyarakat pemodal untuk selanjutnya diinvestasikan dalam Portofolio Efek oleh Manajer Investasi." Terdapat empat macam reksadana yaitu reksadana saham, reksadana campuran, reksadana pendapatan tetap, reksadana pasar uang.

Berdasarkan Single Investor Identification (SID), jumlah investor reksadana terus meningkat dari tahun ke tahun, dengan demografi investor individu berusia 30 tahun ke bawah mendominasi jumlah investor dengan porsi 43,28 persen beraset Rp12,15 triliun. Dengan adanya peningkatan tersebut, reksadana diharapkan mampu menarik peran pemodal dalam negeri atau lokal supaya berinvestasi pada pasar modal Indonesia. Hal itu tentunya akan memberikan manfaat juga mendorong sektor riil bagi perekonomian negara.

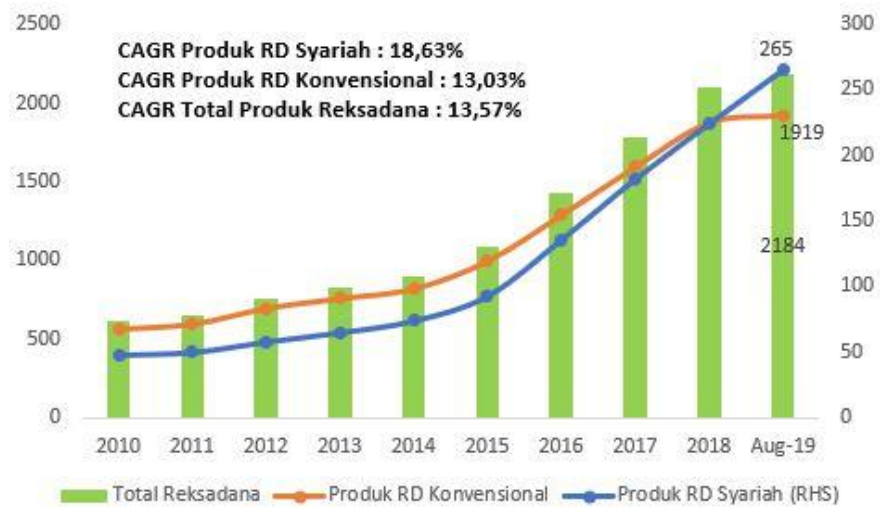

Gambar 1. Perbandingan Jumlah Produk Reksadana

Sumber: OJK, diolah Bareksa

Bersumber pada grafik diatas, reksadana syariah sudah sukses menampilkan eksistensinya di pasar modal syariah dengan terdapatnya kenaikan jumlah produk yang ditawarkan dari tahun ke tahun. Compound Annual Growth (CAGR) atau perkembangan tahunan majemuk produk reksadana Syariah semenjak 2010 sampai Agustus 2019 yakni sebesar 18,63 persen per tahun, mengalahkan produk reksaadana konvensional, walaupun produk reksadana konvensional jauh lebih banyak dibanding produk reksadana syariah. Sehingga bisa dikatakan bila produk reksadana syariah dikala ini mempunyai perkembangan yang lebih besar bila dibandingkan dengan reksadana konvensional.

Seiring meningkatnya jumlah investor reksadana dan jumlah produk reksadana syariah hingga tahun 2019, kinerja terbaik dari syariah diharapkan juga meningkat. Namun faktanya peningkatan jumlah investor reksadana dan jumlah produk reksa dana syariah saham tidak diiringi dengan kinerja positif dari reksadana syariah saham. Rata-Rataterkait kinerja reksadana syariah saham yang ditunjukkan pada nilai Indeks Reksadana Syariah Saham terus mengalami penurunan sepanjang tahun 2019. Berdasarkan data Bareksa, sejak awal tahun hingga September 2019, kinerja rata-rata reksadana syariah saham turun 12,67 persen year-to-date. Jauh lebih besar dibandingkan reksadana 
saham konvensional yang hanya turun 4,77 persen YtD (Sumber: Bareksa). Performa kinerja reksadana secara umum mencatatkan return negatif, dan reksadana syariah saham menjadi reksadana dengan kinerja ekstrim negatif. Walaupun begitu, masih terdapat reksadana syariah saham yang mampu bertahan dalam kondisi ini dengan memiliki kinerja yang lebih baik indeks yang biasa dijadikan acuan reksadana syariah, seperti ISSI dan JII.

Faktor yang mampu mempengaruhi kinerja reksa dana tersebut dapat digolongkan dalam faktor internal dan faktor eksternal (Asriwahyuni, 2017). Pada penelitian ini, penulis memilih empat variabel bebas yang mewakili dua faktor internal dan dua faktor eksternal. Dua faktor internal ditinjau dari sisi kinerja manajer investasi atau fund manager reksadana syariah saham dalam penyeleksian saham (stock selection) yaitu variabel Pemilihan Saham, dan sisi kriteria perusahaan reksadana yaitu variabel Umur Reksa dana. Sedangkan dua faktor eksternal ditinjau dari sisi indeks harga saham syariah di pasar modal yang digambarkan pada Jakarta Islamic Index (JII) dan dari sisi makro ekonomi yaitu Tingkat Inflasi.

Kinerja reksadana syariah saham dapat ditinjau berdasarkan Nilai Aktiva Bersih atau NAB. Tricahyadinata menyatakan bah wa Nilai Aktiva Bersih menginterpretasikan seberapa besar total dana dikelola dalam suatu reksadana (Tricahyadinata, 2016). NAB pada reksadana saham menggambarkan banyak investor yang berinvestasi, menaruh dana pada reksadana saham. Untuk menghitung kinerja reksadana syariah saham secara keseluruhan, penulis memilih untuk menggunakan Sharpe Measure. Sharpe Measure merupakan kinerja portofolio yang dikalkulasikan dengan mengukur return lebih dibagi dengan variabilitas return portofolionya. Besar kecilnya nilai Sharpe Measure menggambarkan semakin baikburuknya kinerja portofolio tersebut.

Dengan penjelasan latar belakang tersebut, maka penulis berfokus untuk melakukan.penelitian dengan judul "Analisis Pengaruh Faktor Internal dan Faktor Eksternal terhadap Kinerja ReksaDana Syariah Saham."

\section{Kajian Pustaka}

\subsection{Kinerja ReksaDana Syariah Saham}

Kinerja reksadana saham menggambarkan kemampuan suatu produk reksadana saham supaya menghasilkan return atau tingkat pengembalian yang kemudian diberikan kepada para investornya (Bitomo, Habib dan Harjum Muharam, 2016). Dengan adanya penilaian terkait kinerja reksadana, tentunya akan membantupenanam modal dalam memilih reksadana yang baik untuk dijadikan tempat menitipkan dananya untuk diinvestasikan. Penilaian terhadap kinerja juga diharapkan mampu menjadi acuan bagi seluruh pihak yang terkait supaya menjaga performa dari reksadana.

\subsection{Pemilihan Saham}

Kemampuan pemilihan saham atau stock selection ability merupakan kemampuan manajer investasi atau fund manager kala memilah efek sekuritas yang tepat untuk kemudian dimasukkan atau dikeluarkan dari portofolio reksadana dengan tujuan untuk memberitingkat pengembalian yang optimal daripada tingkat pengembalian yang normal (Manurung, 2008). Manajer investasi cenderung sering mempercayakan kemampuan pemilihan saham guna menghasilkan return yang abnormal (superior).

Wicaksono dan Sampurno menyatakan bahwasanya variabel stock selection skill atau kemampuan pemilihan saham mempunyai pengaruh positif dan signifikan terhadap kinerja reksadana syariah (Wicaksono dan Sampurno 2017). Nilai koefisien positif menggambarkan apabila semakin tinggi stock selection skill yang dipunyai manajer investasi akan menghasilkan kinerja reksadana syariah yang lebih baik. Gusni mendukung dalam penelitiannya yang menyatakan bahwa stock selectivity skill 
berpengaruh signifikan terhadap kinerja reksadana saham (Gusni, 2018).

Hasil yang bertolak belakang justru didapatkan oleh Panjaitan dimana hasil penelitiannya menunjukkan bahwa stock selection skill diIndonesia tidak berpengaruh yang signifikan pada kinerja reksadana saham (Panjaitan, 2011).

\subsection{Umur ReksaDana}

Umur reksadana merupakan variabel yang menunjukkan usia darisetiap reksadana terhitung sejak tanggal reksadana diperjualbelikan hingga dibutuhkan untuk penelitian. Umur reksadana menunjukkan kapan suatu reksadana mulai diperjualbelikan. Umur juga mampu memainkan peranan kala menentukan kinerja sebab dengan umur yang muda dimungkinkan dapat menghadapi biaya yang lebih besar saat periode awal (Asriwahyuni, 2017).

Reksadana dengan usia yang lebih lama atau tua dianggap mempunyai pengaruh yang jauh lebih bagus terhadap kinerja suatu reksadana (Damayanti dan Cintyawati, 2015). Hal tersebut dapat disebabkan adanya penyesuaian aset suatu reksadana yang berusia lebih lama akan terlihat lebih baik. Bitomo dan Muharam menyatakan bahwa banyak investor lebih menyukai reksadana yang berumur lebih tua dikarenakan reksadana yang memiliki umur yang lebih tua dianggap memiliki pengalaman yang lebih panjang, hal itu dapat menggambarkan kinerja yang lebih baik pada para investornya (Bitomo, Habib dan Harjum Muharam, 2016).

Namun, hasil penelitian Pratama dan Wirama menunjukkan bahwa umur reksadana berpengaruh negatif pada kinerja reksadana saham periode 2012 - 2016 (Pratama dan Wirama, 2018). Hasil penelitian ini sejalan dengan penelitian Wicaksono dan Sampurno yang menyatakan bahwa umur pengaruh negatif terhadap kinerja reksadana syariah. Hal ini justru menunjukkan bahwasanya semakin muda usia reksadana, maka semakin baik pula kinerja reksadananya (Wicaksono dan Sampurno, 2017).

\subsection{Jakarta Islamic Index (JII)}

Jakarta Islamic Index atau JII adalah indeks saham dibentuk berasaskan syariah Islam luncuran PT Bursa Efek Jakarta bersama dengan PT Danareksa Investment Management terkait dengan Pasar Modal Syariah tanggal 3 Juli 2000.

Belum banyak penelitian yang menjadikan JII sebagai variabel penelirian dikarenakan kecenderungan banyak peneliti memilih IHSG. Namun menurut Sholihah saham syariah yang tergabung pada indeks pasar syariah JII memberikan suatu indikasi bahwa sekuritas tersebut lebih berkompeten karena melewati filterisasi berdasarkan kriteria tertentu. Meningkatnya kinerja saham syariah di JII juga memberikan dampak pada peningkatan dana kelolaan reksadana syariah yang menjadikan kinerja reksadana syariah saham menjadi lebih baik (Sholihah, 2018). Sejalan dengan pendapat Sholihah, Wardani menyatakan bahwa Jakarta Islamic Indeks (JII) berpengaruh positif signifikan terhadap Kinerja Reksadana Syariah Saham (Wardani, 2018). Hasil ini menunjukan bahwa JII dapat memberikan pengaruh pada Kinerja Reksadana Syariah Saham.

\subsection{Tingkat Inflasi}

Taqyuddin Ahmad ibn al - Maqrizi (1353-1441) mengatakan seperti dikutip Euis Amalia dalam Bukunya Sejarah Pemikiran Ekonomi Islam dari Masa Klasik bingga Kontemporer, bahwasanya inflasi terjadi kala harga-harga secara umum mengalami kenaikan secara terus-menerus. Kala itu, terjadi kelangkaan pada ketersediaan barang dan jasa ketika disatu sisi konsumen diwajibkan mengeluarkan lebih banyak uang untuk sejumlah barang serta jasa yang sama. 
Gusni menyatakan bahwa inflasi berpengaruh positif signifikan terhadap kinerja reksadana saham (Gusni, 2018). Penelitian ini didukung oleh Wardani bahwa inflasi berpengaruh positif terhadap Kinerja Reksadana Syariah Saham (Wardani, 2018).

Namun, hasil bertentangan didapat dari penelitian terbaru oleh Dalimunthe dan Lestari bahwa inflasi berpengaruh negatif terhadap reksadana saham (Dalimunthe dan Lestari, 2019). Sejalan dengan penelitian sebelumnya, Pratama dan Wirama menyatakan bahwa inflasi berpengaruh negatif terhadap kinerja reksadana saham periode 2012 - 2016 (Pratama dan Wirama, 2018).Itu artinya, saat terjadi inflasi justru kinerja reksadana menurun. Karena daya beli masyarakat yang rendah menyebabkan harga reksadana saham menurun yang selanjutnya akan berpengaruh terhadap Kinerja Reksadana Syariah Saham.

\section{Metode Penelitian}

\subsection{Metode Penelitian, Jenis Data, dan Sumber Data}

Metode penelitian yang diaplikasikan pada penelitian adalah metode deskriptif. Tujuan dari metode tersebut adalah membantu menggambarkan atau menganalisis suatu peristiwa yang sedang terjadi sekarang atau dalam kurun waktu tertentu dan melihat sebab-sebab terjadinya suatu gejala tertentu.

Sedangkan untuk jenis data yang diaplikasikan adalah data kuantitatif yang dipublikasikan oleh Bareksa melalui websitenya https://m.bareksa.com dan www.ojk.go.id. Data variabel lainnya seperti Jakarta Islamic Index dipublikasikan secara harian melalui website https:/ / duniainvestasi.com dan Tingkat Inflasi dipublikasikan oleh Bank Indonesia (BI) pada website www.bi.go.id terhitung sejak dari Januari 2017-Desember 2019.

\subsection{Definisi dan Operasional Variabel}

Dalam penelitian ini digunakan empat variabel untuk diuji sebagai faktor yang diharapkan mempunyai pengaruh terhadap kinerja reksadana syariah saham yaitu Pemilihan Saham, Umur reksa dana, Jakarta Islamic Index, dan Tingkat Inflasi.

Kinerja Reksa Dana Syariah Saham menunjukkan kemampuan suatu produk reksadana perihal menghasilkan return atau tingkat pengembalian yang diberikan oleh suatu reksadana kepada para investor. Sharpe memperkenalkan RVAR (Reward to Variabelity Ratio) sebagai pengukur kinerja portofolio yang dikalkulasikan dengan membagireturn lebih (excess return) dengan variabilitas dari return portofolio atau standard deviation (Sharpe, 2005). Excess return dihasilkan dari Ri - Rf. Pendekatan SCAPM digunakan pada penelitian ini dengan pertimbangannya yang tidak mengakui risk free (Rf) maka Rf digantikan oleh SBIS. Satuan hitung variabel ini adalah desimal.

Pemilihan saham adalah keahlian Manajer Investasi dalam memilah efek sekuritas yang cocok diinput ataupun keluar dari portofolio reksadana. Model Treynor-Mazuy menjadi alat ukur dalam perhitungan variabel ini. Pengaruh variabel pemilihan saham direpresentasikan oleh $\alpha$ (alpha) dan nilai besaran $\chi$ (chi) diabaikan. Apabila manajer investasi mempunyai $(\alpha>0)$ maka ada kemampuan pemilihan saham yang baik, begitu pula sebaliknya. Satuan hitung variabel ini adalah desimal.

Umur reksadana merupakan variabel yang menggambarkan usia dari tiap reksadana terhitung sejak tanggal reksadana tersebut efektif diperjualbelikan. Arifah dkk. menyatakan umur reksadana didapatkan dari pengurangan periode penelitian terhadap tanggal efektif reksa dana diperdagangkan lalu diubah dalam bentuk Ln (Arifah dkk., 2019). Satuan hitung variabel ini adalah desimal.

Jakarta Islamic Index merupakan indeks saham yang dibentuk berlandaskan syariat Islam karya PT Bursa Efek Jakarta bersama dengan PT Danareksa Investment Management. JII diukur dengan return aktual bulanan saham JII. Satuan hitung variabel ini adalah desimal. 
Inflasi merupakan kenaikan tingkat harga umum secara terus - menerus yang memengaruhi individu, perusahaan serta pemerintah. Inflasi yang ditinjau dari sisi perekonomian secara makro dihitung menggunakan Indeks Harga Implisit atau Deflator PDB. Satuan hitung variabel ini adalah persentase.dihitung menggunkan Indeks Harga Implisit atau Deflator PDB. Data Inflasi diperoleh dari BI (www.bi.go.id) terhitung sejak Januari 2017-Desember 2019). Satuan hitung variabel ini adalah persentase.

\subsection{Teknik Analisis Data}

Penelitian ini memilih software WarpPLS 7.0 dengan metode analisis jalur (path analysis) sebagai teknik analisis data. Metode analisis jalur dilakukan melalui beberapa tahap diantaranya merancang model didasarkan pada teori, pengembangan path diagram atau diagram jalur, konversi diagram jalur kedalam persamaan, uji Goodness of Fit Model, uji hipotesis hingga interpretasi hasil analisis.

Langkah selanjutnya dalam penelitian ini adalah melakukan ujistatistik-deskriptif dengan menampilkan rata-rata data (mean), nilaimaksimum (max) dari setiap variabel uji, nilai minimum (min) dari setiap variabel uji, dan standar deviasi.

Baik tidaknya fungsi regresi sampel yang digunakan dalam penelitian ini akan diuji kelayakannya dengan yang biasa dikenal sebagai Goodness of Fit Model. Fit atau tidaknya sebuah model terlihat berdasarkan nilai Average path coefficient (APC), Average R-squared (ARS), Average adjusted R-squared (AARS), Average block VIF (AVIF), Average full collinearity VIF (AFVIF), Tenenhaus GoF (GoF), Sympson's paradox ratio (SPR), R-squared contribution ratio (RSCR), Statistical suppression ratio (SSR), dan Nonlinear bivariate causality direction ratio (NLBCDR). Sedangkan hasil uji hipotesis pada penelitian ini ditinjau berdasarkan nilai yang muncul pada diagram jalur. Empat hipotesis tersebut antara lain:

a. Hipotesis 1

$\mathrm{H}_{0}$ : PS (Pemilihan Saham) tidak berpengaruh signifikan terhadap KRS (Kinerja ReksaDana Syariah Saham).

Ha: PS (Pemilihan Saham) berpengaruh signifikan terhadap KRS (Kinerja ReksaDana Syariah Saham).

b. Hipotesis 2

$\mathrm{H}_{0}$ : UMR (Umur ReksaDana) tidak berpengaruh signifikan terhadap KRS (Kinerja ReksaDana Syariah Saham).

Ha: UMR (Umur ReksaDana) berpengaruh signifikan terhadap KRS (Kinerja ReksaDana Syariah Saham).

c. Hipotesis 3

$\mathrm{H}_{0}$ : JII (Jakarta Islamic Index) tidak berpengaruh signifikan terhadap KRS (Kinerja ReksaDana Syariah Saham).

Ha: JII (Jakarta Islamic Index) berpengaruh signifikan terhadap KRS (Kinerja ReksaDana Syariah Saham).

d. Hipotesis 4

$\mathrm{H}_{0}$ : INF (Tingkat Inflasi) tidak berpengaruh signifikan terhadap KRS (Kinerja ReksaDana Syariah Saham).

Ha: INF (Tingkat Inflasi) berpengaruh signifikan terhadap KRS (Kinerja ReksaDana Syariah Saham).

Berdasarkan keempat hipotesis di atas, dasar pengambilan keputusan adalah apabila p-value $\geq$ 0,05, maka Ho diterima. Sebaliknya apabila p-value $<0,05$, maka Ho ditolak dan Ha diterima. 


\section{Hasil dan Pembahasan}

\subsection{Hasil Statistik Deskriptif}

Berdasarkan metode purpose sampling yang digunakan, terdapat 6 perusahaan memenuhi kriteria yang dibutuhkan. Hasil statistik deskriptif yang didapat adalah sebagai berikut:

Tabel 1: Statistik Deskriptif Data Penelitian

\begin{tabular}{|c|c|c|c|c|c|}
\hline & n'T & MEAN & MIN & MAX & STDEV \\
\hline PS & 216 & -0.001 & -0.107 & 0.114 & 0.016 \\
\hline UMR & 216 & 4.719 & 3.664 & 5.050 & 0.339 \\
\hline JII & 216 & 0.001 & -0.076 & 0.050 & 0.027 \\
\hline INF & 216 & 0.033 & 0.025 & 0.044 & 0.004 \\
\hline KRS & 216 & 0.003 & -0.075 & 0.110 & 0.027 \\
\hline
\end{tabular}

Sumber: WarpPLS, data diolah penulis

Nilai PS menghasilkan nilai rata-rata sebesar -0.001 dengan nilai minimum PS dimiliki oleh reksadana Syariah Saham Manulife Syariah Sektoral Amanah dan nilai maksimum PS dimiliki oleh reksadana Syariah Saham Sucorinvest Sharia Equity Fund. PT. Sucorinvest Asset Management sebagai pemilik reksadana tersebut memiliki kinerja manajer investasi terbaik berdasarkan taktik pemilihan sahamnya. Besar standar deviasi PS didapat sebesar 0.016.

Nilai UMR memiliki nilai rata-rata sebesar 4.719 dengan nilai minimum UMR dimiliki oleh reksadana Syariah Saham Sucorinvest Sharia Equity Fund dan nilai maksimum UMR dimiliki oleh reksadana Syariah Saham TRIM Syariah Saham. PT. Trimegah Asset Management sebagai pemilik reksadana tersebut memiliki pengalaman sepak terjang reksadana terlama dengan usia reksadana tertua. Standar deviasi UMR didapat didapat sebesar 0.339.

Nilai JII mempunyainilai rata-rata dengan nilai minimum JII yang terjadi pada Mei 2019 dan nilai maksimum JII terjadi pada Januari 2018. Januari 2018 menjadi waktu dengan cetak nilai indeks pergerakan saham JII tertinggi dalam periode 3 tahun terhitung sejak Januari 2017 hingga Desember 2019. Besar standar deviasi JII didapat sebesar 0.027.

Nilai INF menunjukkan nilai rata-rata sebesar 0.033 dengan nilai minimum INF terjadi pada Maret 2019 dan nilai maksimum INF terjadi pada Juni 2017. Juni 2017 menjadi waktu dengan tingkat inflasi tertinggi dalam periode 3 tahun terhitung sejak Januari 2017 hingga Desember 2019. Besar standar deviasi INF didapat sebesar 0.004.

Sedangkan nilai KRS mempunyai nilai rata-rata sebesar 0.003 dengan nilai minimum KRS dimiliki oleh reksadana Syariah Saham Manulife Syariah Sektoral Amanah dan nilai maksimum KRS dimiliki oleh reksadana Syariah Saham CIMB - Principal Islamic Equity Growth Syariah. PT. CIMB - Principal Asset Management sebagai pemilik reksadana tersebut memiliki kinerja reksadana Syariah Saham terbaik dalam periode 3 tahun terhitung sejak Januari 2017 hingga Desember 2019. Besar standar deviasi KRS didapat sebesar 0.027.

\subsection{Pengembangan Path Diagram atau Analisis Jalur}

Berikut merupakan hasil analisis jalur dari seluruh variabel yang diuji secara parsial beserta ringkasan hasil uji hipotesis masing-masing variabel: 


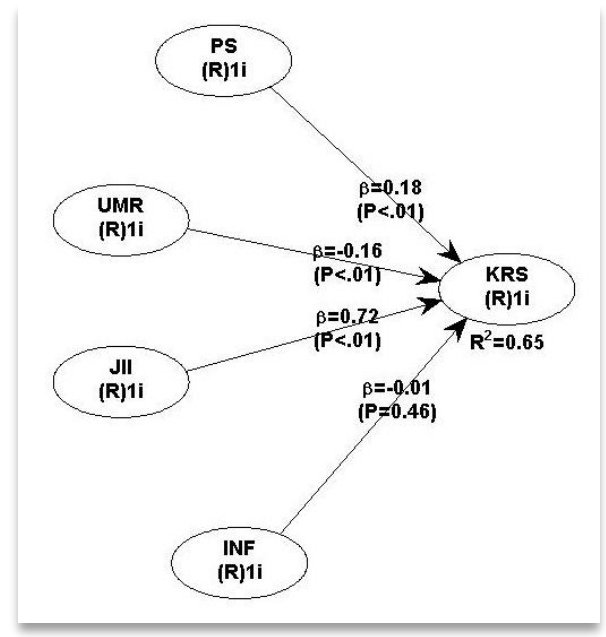

Gambar 2. Pengujian Model Direct Effect

Sumber: WarpPLS, data diolah penulis.

Tabel 2. Ringkasan Hasil Uji Hipotesis

\begin{tabular}{|c|c|c|c|c|c|}
\hline No. & Variabel & $\begin{array}{c}\text { Sign. } p \text { - } \\
\text { value }\end{array}$ & $\begin{array}{c}\text { Penolakan } \\
\text { Penerimaan } \\
\mathrm{H}_{0}\end{array}$ & $\begin{array}{c}\text { Koefisien } \\
\text { Jalur }\end{array}$ & Keterangan \\
\hline 1 & PS $\rightarrow$ KRS & $\mathrm{P}<0.01$ & Ditolak & 0.18 (Positif) & Berpengaruh signifikan \\
\hline 2 & UMR $\rightarrow$ KRS & $\mathrm{P}<0.01$ & Ditolak & $\begin{array}{c}-0.16 \\
\text { Negatif) }\end{array}$ & $\begin{array}{c}\text { Berpengaruh } \\
\text { signifikan }\end{array}$ \\
\hline 3 & JII $\rightarrow$ KRS & $\mathrm{P}<0.01$ & Ditolak & 0.72 (Positif) & Berpengaruh signifikan \\
\hline 4 & INF $\rightarrow$ KRS & $\mathrm{P}=0.46$ & Diterima & $\begin{array}{c}-0.01 \\
\text { Negatif) }\end{array}$ & $\begin{array}{c}\text { Tidak berpengaruh } \\
\text { signifikan }\end{array}$ \\
\hline
\end{tabular}

Sumber: WarpPLS, data diolah penulis

\section{Pemilihan Saham}

Hasil output WarpPLS menunjukkan bahwa Pemilihan Saham (PS) mempunyai pengaruh signifikan positif terhadap Kinerja ReksaDana Syariah Saham (KRS). Nilai positif mengindikasikan bahwa semakin tinggi kemampuan pemilihannsaham berimbas pada kinerja reksadana syariah saham yang semakin baik pula.

Sesuai dengan penjelasan secara teori, biasanya manajer investasi telah mempunyai kelompok saham pilihan lalu dilakukan buy and hold untuk masa tertentu hingga harga saham menarik untuk diperjualbelikan (Rudiyanto, 2015). Adapun pilihan saham dengan kinerja manajer investasi yang baik tentu akan membangun citra reksa dana yang baik dan memikat investor untuk menanamkan dananya pada reksadana tersebut. Dengan meningkatnya dana kelolaan yang ada akan meningkatkan potensi tingkat return yang optimal dan kinerja reksadana yang positif.

\section{Umur ReksaDana}

Variabel Umur ReksaDana (UMR) menunjukkan pengaruh secara signifikan negatif terhadap variabel Kinerja ReksaDana Syariah Saham (KRS). Nilai koefisien negatif mengindikasikan sebuah hubungan terbalik dimana semakin muda umur reksadana -terhitung sejak reksadana diterbitkan-, maka kinerja reksadana syariah saham semakin baik. Nilai negatif tersebut mengungkapkan bahwa 
reksadana baru dianggap memiliki kemampuan beradaptasi terhadap perkembangan zaman yang pesat. Kemudahan untuk mengakses segala informasi saat ini, khususnya terkait perkembangan reksadana syariah saham diduga menjadi faktor kunci reksadana muda untuk belajar dari pengalaman reksadana terdahulu. Kemungkinan lain yang dapat terjadi adalah gagalnya perusahaan reksadana yang berumur tua untuk mempertahankan eksistensinya sebagai pihak yang seharusnya memiliki nilai lebih dari sisi pengalaman.

\section{Jakarta Islamic Index}

Hasil output WarpPLS menunjukkan pengaruh positif terhadap Kinerja ReksaDana Syariah Saham (KRS). Nilai koefisien positif mengindikasikan bahwa semakin tinggi pergerakan indeks saham pada Jakarta Islamic Index dalam suatu periode, kinerja reksadana syariah akan makin baik jua.

Penelitian terdahulu banyak yang memilih IHSG sebagai patokan utama dibandingkan dengan JII yang memiliki usia lebih muda dalam dunia pasar modal, bahkan untuk penelitian saham syariah. Namun berdasarkan penelitian ini, indeks pasar modal syariah JII saat ini menjadi lebih kokoh dan terpercaya sehingga memberikan nilai pada saham syariah yang tergabung didalamnya sebagai saham berkompeten dan baik. Dengan saham-saham yang terpercaya, tentu saja terdapat dana kelolaan yang besar. Reksadana Syariah Saham yang masuk kedalam indeks pasar syariah JII tentu akan berdampak pada meningkatnya kinerja Reksaadana Syariah Saham dan return yang optimal.

\section{Tingkat Inflasi}

Tingkat inflasi (INF) merupakan variabel yang menunjukkan tidak adanya pengaruh signifikan terhadap Kinerja ReksaDana Syariah Saham (KRS). Ketika inflasi meningkat maka Bank Sentral yaitu Bank Indonesia dengan wewenangnya sebagai pemegang otoritas tertinggi akanmengambil kebijakan moneter berupa kebijakan menaikkan suku bunga. Dengan naiknya tingkat suku bunga diharapkan akan mendorong investor untuk menanamkan modalnya pada sekuritas. Hal ini tentu berdampak pada pasar saham dimana para investor lebih tertarik untuk beralih menanamkan modalnya pada sekuritas dibandingkan ekuitas seperti saham. Aliran dana semakin berkurang menyebabkan harga saham menurun dan kinerja reksadana saham pun menurun.

Penelitian oleh Dalimunthe dan Lestari tahun 2019 dan penelitian Pratama dan Wirama (2018) menyatakan bahwa inflasi berpengaruh signifikan negatif terhadap reksa dana saham. Penelitian tersebut dilakukan pada periode 2012-2016 dimana periode tersebut merupakan periode dengan rata-rata tingkat inflasi sebesar 6\%. Sedangkan penelitian ini dilakukan dengan menggunakan sampel terhitung sejak Januari 2017 hingga akhir 2019 dimana rata-rata tingkat inflasi hanya 3\%. Dengan rendahnya tingkat inflasi pada periode ini dapat menyebabkan kinerja reksadana saham yang semakin baik hingga cenderung stabil dan tidak terikat dengan tingkat inflasi. Perbedaan kondisi tingkat inflasi yang cukup besar dapat menjadi faktor mengapa hasil penelitian ini berbeda dari penelitian sebelumnya dan menjadikannya tidak berpengaruh secara signifikan meskipun sifatnya tetap sama yaitu negatif.

\subsection{Pengujian Goodness of Fit Model}

Uji Goodness of Fit Model untuk seluruh faktor internal dan faktor eksternal terhadap Kinerja ReksaDana Syariah Saham dinterpretasikan dalam tabel berikut. 


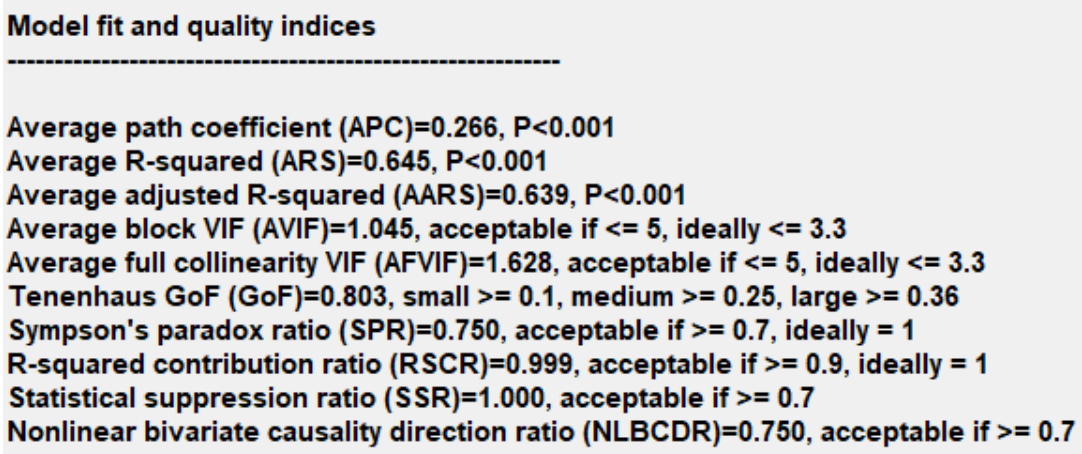

Gambar 3. Goodness of Fit Model

Sumber:WarpPLS, data diolah penulis

Dengan diterimanya seluruh Goodness of Fit Index, maka Goodness of Fit Model secara parsial dapat diterima dan model penelitian layak untuk diuji.

\section{Penutup}

\subsection{Kesimpulan}

1. Pengungkapan PS atau Pemilihan Saham berpengaruh signifikan terhadap Kinerja ReksaDana Syariah Saham periode 2017-2019 bersifat positif. Apabila pemilihan saham dilaksanakan dengan benar berpotensi membangun citra reksadana yang baik dan memperbesar dana kelolaan dari para investor untuk kemudian dikelola supaya mencapai return optimal dan meningkatkan Kinerja ReksaDana Syariah Saham Saham.

2. Pengungkapan UMR atau Umur ReksaDana berpengaruh secara signifikan terhadap Kinerja ReksaDana Syariah Saham periode 2017-2019 dengan sifat negatif. Dapat disimpulkan bahwa diungkapkannya umur reksa dana mempengaruhi Saham dengan sifat negatif yang dapat ditimbulkan akibat gagalnya perusahaan reksadana yang berumur tua untuk mempertahankan eksistensinya sebagai pihak yang seharusnya memiliki nilai lebih dari sisi pengalaman dan reksadana baru dianggap memiliki kemampuan beradaptasi terhadap perkembangan zaman yang pesat.

3. Pengungkapan JII atau Jakarta Islamic Index berpengaruh signifikan terhadap Kinerja ReksaDana Syariah Saham periode 2017-2019 dengan sifat positif. Dapat disimpulkan bahwa apabila Jakarta Islamic Index diungkapkan dengan baik maka akan membentuk indeks pasar modal syariah JII yang terpercaya, menginterpretasikan kumpulan saham berkompeten. Tentunya hal ini akan meningkatkan kepercayaan investor dengan semakin besarnya dana kelolaan dari para investor untuk kemudian dikelola dalam usaha mencapai return optimal dan meningkatkan kinerja reksa dana Syariah Saham.

4. Pengungkapan INF atau Tingkat Inflasi tidak berpengaruh secara signifikan terhadap Kinerja ReksaDana Syariah Saham periode 2017-2019. Dapat disimpulkan bahwa tidak signifikannya hasil penelitian ini mungkin terjadi akibat adanya keterbatasan periode yang dilakukan peneliti dan adanya penurunan drastis tingkat inflasi pada masa peralihan 2016-2017 dengan selisih rata-rata mencapai 3\%. Dengan rendahnya tingkat inflasi menyebabkan Kinerja ReksaDana Syariah Saham tidak terpengaruh secara signifikan terhadap adanya perubahan tingkat inflasi.

\subsection{Saran}

1. Perbedaan pengungkapan dan kemudahaan mengakses data terkait reksadana -khususnya reksadana Syariah Saham- pada situs Bareksa sebagai situs utama reksadana belum tertata 
dengan format yang sama dari setiap reksadana serta masih sulit untuk diakses bahkan untuk data umum. Pembenahan format pengungkapan yang sama bagi seluruh reksadana dan kemudahan akses terkait produk reksadana sangat diperlukan supaya dapat memenuhi kriteria data dan memperbanyak data yang dapat lolos uji.

2. Perusahaan reksadana diharapkan lebih memerhatikan kesejahteraan tenaga kerja terutama para manajer investasi demi tercapainya kinerja perusahaan dan reksadana yang semakin baik.

3. Dalam penelitian selanjutnya diharapkan menggunakan lebih banyak sampel perusahaan seiring dengan diperbaikinya format data terkait reksadana yang lebih detil dan mudah untuk diakses.

4. Penelitian selanjutnya dapat menambahkan jumlah variabel independen supaya hasil penelitian yang diperoleh lebih beragam.

\section{Daftar Pustaka}

Arifah, I. d. (2019). Faktor-Faktor yang mempengaruhi Kinerja Reksa dana Syariah di Indonesia dan Malaysia. Conference on Islamic Management, Accounting, and Economics (CIMAE) Proceeding. Vol. 2, (pp. 190-206).

Asriwahyuni, P. (2017). Pengaruh Ukuran dan Umur Pada Kinerja Reksa dana Saham di Indonesia.E-Jurnal Akuntansi Universitas Udayana, 21 (2), 1460-1487.

Bitomo, Habib dan Harjum Muharam. (2016). Analisis Faktor-Faktor yang Mempengaruhi Kinerja Reksa dana di Indonesia (Studi Empiris Pada Reksa dana Konvensional di Indonesia Periode 2012 - 2014). Diponegoro Journal of Management, 5 (2), 1-14.

Dalimunthe, Ibram P. dan Ajeng Desni Lestari. (2019). Effect of Inflation and Price Index on Equity Assets. Economics and Accounting Journal Vol. 2, No.1.

Damayanti S.M. dan Cici Cintyawati. (2015). Developing an Integrated Model of Equity Mutual Funds Performance: Evidence from the Indonesian Mutual Funds Market. GSTF Journal on Business Review (GBR) Vol.4 No.1.

Gusni, Silviana and Faisal Hamdani. (2018). Factors affecting equity mutual fund performance: evidence from Indonesia. Investment Management and Financial Innovations, 15(1), 1-9.

Manurung, A. (2008). Reksa dana Investasiku. Jakarta: Kompas

Pratama, I Putu Bayu Suyadnya dan Dewa Gede Wirama . (2018). Pengaruh Inflasi, IHSG, Ukuran Dan Umur Pada Kinerja Reksa dana Saham Periode 2012 - 2016. E-Jurnal Manajemen Unud Vol.23 (2), 842-870.

Rudiyanto. (2015). Reksa dana untuk Pemula. Jakarta: Elex Media Komputindo.

Sharpe, F. William, et al. Alih Bahasa Pristina Trimastuti dkk. (2005). Investment. Edisi 6. Jakarta:: PT. Indeks Kelompok Gramedia.

Sholihah, A. (2008). Analisis Pengaruh JII, SWBI, IHSG, dan Inflasi Terbadap Kinerja Reksa dana Syariah. Jakarta: Universitas Islam Negeri Syarif Hidayatullah

Wicaksono, Muhammad Pambudi dan R. Djoko Sampurno . (2017). Analisis Pengaruh Fund Age, Market Timing Ability, Stock Selection Skill, Portfolio Turnover,dan Fund Size terhadap Kinerja Reksa dana Syariah Periode 2013-2015. Diponegoro Journal of Management, 6 (3), 1-11.

Tricahyadinata, I. (2016). Indeks Harga Saham Gabungan (IHSG) dan Jakarta Interbank Offered Rate (JIBOR); Kinerja Reksa dana Campuran . Jurnal Ekonomi Kenangan dan Manajemen, 12 (2), 281-310.

Wardani, I. K. (2018). Analisis Pengaruh Jakarta Islamic Index (JII) Inflasi dan Kemampuan Manajer Investasi Terbadap Kinerja Reksa dana Syariah Saham. Yogyakarta: Universitas Islam Indonesia. 